\title{
Impact of land use change on water resource allocation in the middle reaches of the Heihe River Basin in northwestern China
}

\author{
YanYun NIAN ${ }^{1,2^{*}}$, Xin $\mathrm{LI}^{1}$, Jian $\mathrm{ZHOU}^{1}$, XiaoLi HU ${ }^{1}$ \\ ${ }^{1}$ Cold and Arid Regions Environmental and Engineering Research Institute, Chinese Academy of Sciences, Lanzhou 730000, China; \\ ${ }^{2}$ College of Earth and Environmental Sciences, Lanzhou University, Lanzhou 730000, China
}

\begin{abstract}
In recent decades, China has been experiencing rapid economic development, population growth and urbanization. These processes have stressed the shortages of water resources in China, especially in the arid regions of northwestern China. In order to sustain the expanding cropland, people increased groundwater exploitation in these regions. The purpose of this study was to quantitatively analyze the changes in land use and water resources, and their relationship in the middle reaches of the Heihe River Basin, a typical inland river basin in northwest China. The data of land use change were interpreted using aerial photographs (1965) and Landsat TM images (1986 and 2007). The data of irrigation water volume in the irrigation districts were spatialized in the middle reaches of the Heihe River Basin. The spatial variation of the groundwater depth was interpolated using the geostatistical method. The results showed that the cultivated cropland area along oasis fringe increased by $15.38 \%$ and $43.60 \%$ during the periods $1965-1986$ and $1986-2007$, respectively. Surface water amount for irrigation had almost doubled from 1956 to 2010. The decrease of grassland area mainly occurred at the alluvial fan in front of the Qilian Mountains, with 36.47\% during 1965-1986 and 38.56\% during 1986-2007, respectively. The groundwater depth in front of the mountain constantly increased from 1986 to 2007. We found that the overuse of surface water and overexploitation of groundwater had direct consequences on the natural environments. We suggests that the efficiency of surface water resources use among different irrigation districts needs to be improved, which will significantly ease the conflicts between increasing water demand for irrigation and a shortage of water resources in the middle reaches of the Heihe River Basin.
\end{abstract}

Keywords: watershed management; land use; groundwater; irrigation; arid region; Heihe River Basin

Citation: YanYun NIAN, Xin LI, Jian ZHOU, XiaoLi HU. 2014. Impact of land use change on water resource allocation in the middle reaches of the Heihe River Basin in northwestern China. Journal of Arid Land, 6(3): 273-286. doi: 10.1007/s40333-013-0209-4

Land use and land cover changes are among the most important factors to be considered in global change study (Houghton, 1994; Lambin, 1997; Loveland et al., 2000). Land use describes the exploitation and utilization of land resources by humans, e.g. through agriculture and urbanization (Pielke et al., 2002). Many international programs, including the International Geosphere-Biosphere Program (IGBP), the International Human Dimension Program (IHDP), the World Climate
Research Program (WCRP), and DIVERSI TYS (an international program of biodiversity science), have initialized some projects to investigate the relationship between land use and the hydrological cycle (Hoff, 2002; Lambin et al., 2002). On the one hand, land use change is the result of both natural processes and anthropogenic activities. An increasing number of studies have shown that humans can partially understand ecosystem changes by studying the modes of land use in

*Corresponding author: YanYun NIAN (E-mail: yynian@1zu.edu.cn) Received 2013-05-02; revised 2013-09-06; accepted 2013-10-25

(C) Xinjiang Institute of Ecology and Geography, Chinese Academy of Sciences, Science Press and Springer-Verlag Berlin Heidelberg 2014 
the past, present, and future (Turner et al., 2003). On the other hand, land use is a major force that can alter hydrological processes over the range of temporal and spatial scales in arid regions, e.g. the partitioning of precipitation into evapotranspiration, runoff, and groundwater flow (Foley et al., 2005; Leng et al., 2011).

The understanding consequences of land use change for hydrologic processes are major needs for the future (Turner et al., 2003). These consequences include: changes in water demands from changing land use practices, such as irrigation and urbanization; changes in water supply from altered hydrological processes of infiltration, groundwater recharge and runoff; and changes in water quality from agricultural runoff and suburban development (DeFries and Eshleman, 2004). Land use impact on water resources has been carried out in different watersheds with a focus on water scarcity (Calow et al., 1997; Scanlon et al., 2007; Chen et al., 2009; Raini, 2009; Wagner et al., 2013). Ozturk et al. (2013) assessed the impact of land use change on the watershed hydrological processes in the Bartin Spring, northwestern Turkey. The results showed that the water budget is most sensitive to the conversion between grass and agricultural lands. Mellander et al. (2013) studied the effect of land use on water management in Ethiopian Blue Nile Basin (BNB), and suggested that the characteristic of spatiotemporal zonation should be considered. Choi and Deal (2008) researched the hydrological impact of potential land use change using hydrological and land use change modeling in the Kishwaukee River Basin in midwestern USA. The results indicated that land use dynamics had a significant impact on exchange between surface water and groundwater. Im et al. (2009) used MIKE SHE to investigate hydrologic response to land use changes within the Gyeongancheon watershed in Korea. Land use practices had important impacts on both the availability and quality of water resources. Baker and Miller (2013) used the SWAT model to assess land use impact on water resources in an East African watershed, and found that land use changes have resulted in corresponding increases in surface runoff and decreases in groundwater recharge. These changes had negative implications for the eco- logical health of the river system. In summary, the impact of land use on water resources is reflected by hydrologic process and supply-demand relationship of water resources (Wang and Cheng, 2000; Chen et al., 2006). Therefore, the investigation of the dynamic changes in different modes of water utilization and the analysis on reasons for these changes will provide a scientific basis for planning and managing the watershed environment.

As the second largest inland river basin in the arid region of northwestern China, the Heihe River Basin has faced severe limited water resource competition between economic development and eco-environment services (Ji et al., 2006), land desertification (Li et al., 2001), and soil salinization (Qi and Luo, 2006). Many studies have been conducted on land use change and its relationship with hydrological processes in the Heihe River Basin. These studies have investigated water resource development (Gao and Li, 1991; Wang, 1997), land use change and landscape evolution and their driving factors (Lu et al., 2003), the responses of hydrological processes and water resources to land use change (Wang et al., 2005; Wang et al., 2007), and the estimation of the ecological water requirements of vegetation (Wang et al., 2002; Zhao et al., 2007; Guo, 2010; Jin and $\mathrm{Hu}, 2010$ ). However, the aforementioned work has focused on the land use change since 1980s. There is still lack of long time series of land use and water allocation data, therefore, the long-term impacts of land use on the water resources in the middle reaches of the Heihe River Basin are poorly understood.

The objectives of this research are to analyze how land use and water resources utilization changed over the last 40 years and to evaluate the impact of land use change on water resource utilization in the middle reaches of the Heihe River Basin.

\section{Materials and methods}

\subsection{Study area}

The study area is located in the middle reaches of the Heihe River Basin $\left(38^{\circ} 30^{\prime} \mathrm{N}-39^{\circ} 55^{\prime} \mathrm{N}, 98^{\circ} 55^{\prime} \mathrm{E}-100^{\circ}\right.$ $55^{\prime} \mathrm{E}$; Fig. 1). The total area is $11,300 \mathrm{~km}^{2}$. The mean annual precipitation is $69-216 \mathrm{~mm}$ and is concentrated 
between June and September. The mean annual potential evaporation is $1,453-2,351 \mathrm{~mm}$. The major rivers in the study area are the mainstream of the Heihe River and its tributaries, the Liyuan and Daciyao rivers. After the Heihe River flows out of the mouth of the Qilian Mountains, with an average runoff $17.3 \times 10^{8}$ $\mathrm{m}^{3} / \mathrm{a}$, in which $13.0 \times 10^{8} \mathrm{~m}^{3} / \mathrm{a}$ is used to irrigate. Flood irrigation causes a part of irrigation water return to the groundwater system. The study area has highly developed irrigation agriculture, with an agricultural history dating back to about 2,000 years ago. In Yingluo gauge station located at the mouth of the Qilian Mountains, the streamflow from mountainous area is measured. The Heihe River eventually flows into the delta plain in the lower reaches through the Zhengyi gauge station, with an average runoff volume of about $9.0 \times 10^{8} \mathrm{~m}^{3} / \mathrm{a}$.

More than $40 \%$ of the population and $60 \%$ of the cropland in the Heihe River Basin are concentrated in the study area and $70 \%$ of the water resources from the mainstream of the Heihe River are consumed here (according to 2008 statistical data from the Gansu
Provincial Bureau of Statistics). These is a relatively complete irrigation system of more than 893 main canals and branch canals, with a total length of 4,415 $\mathrm{km}$. The exploitation of groundwater resources had a 200-year history in the middle reaches of the Heihe River Basin. The exploitation was very limited before the 1970s, but after the 1980s groundwater had been extensively exploited (Wang et al., 2008). Figure 1 illustrates the rapid increase in the number of pumping wells along the Heihe River in the two periods of the 1990s and 2000s. The shortage of water resources has become a bottleneck for socioeconomic development in the middle reaches of the Heihe River Basin. After obtaining authorization from the State Council in 2001, the Ecological Water Transfer Project (EWTP) of the Heihe River Basin was implemented with the objective of allowing more water to be used in the lower reaches. The implementation of the EWTP has changed the trends of land degradation and ecological deterioration in the lower reaches of the Heihe River Basin (Zhang et al., 2011).

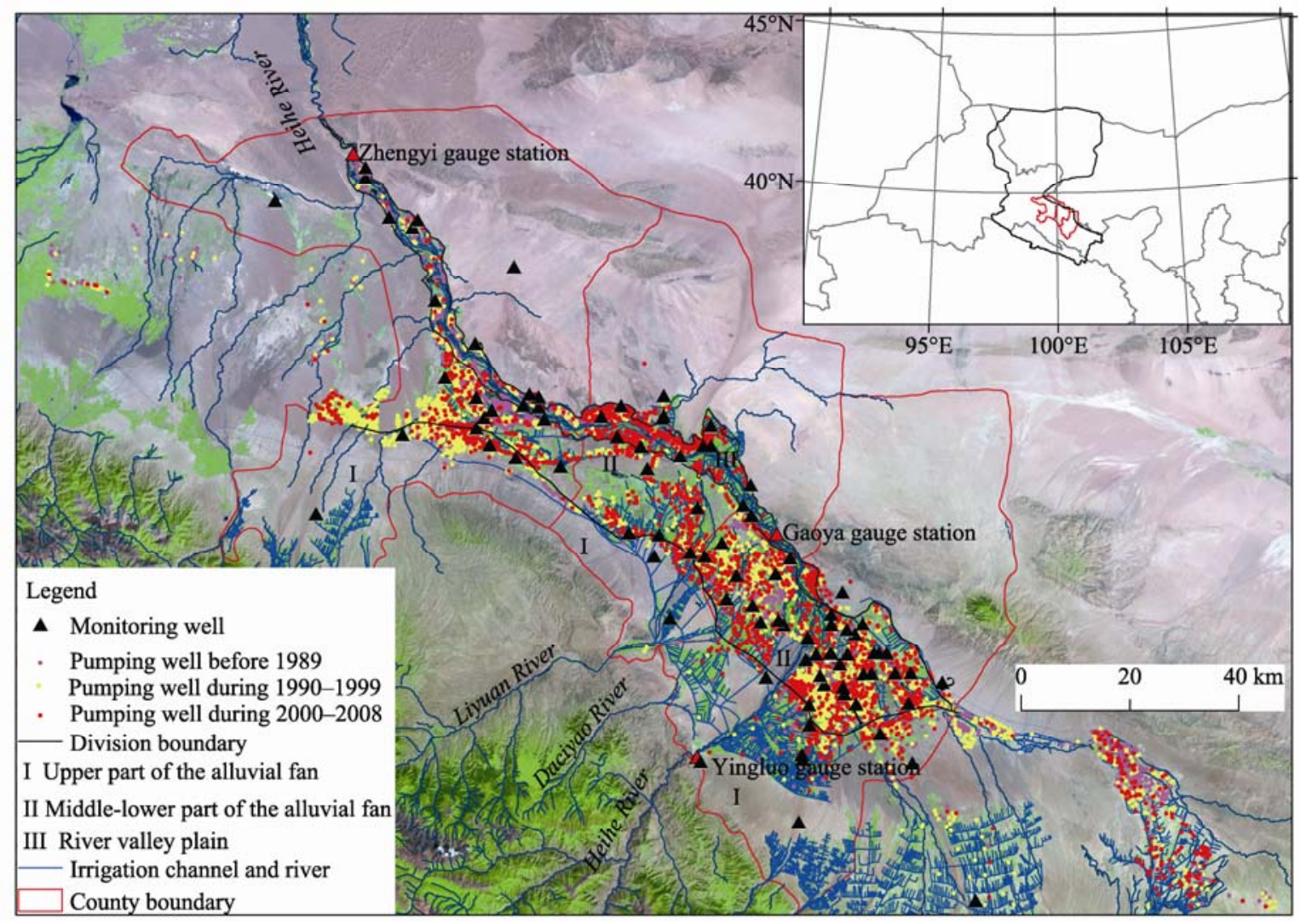

Fig. 1 Map of the canal irrigation system, groundwater exploitation wells, and monitoring wells in the study area 


\subsection{Data collection}

Land use data acquired through visual interpretation of aerial photographs in 1965 (Wang et al., 2007) and Landsat TM/ETM+ images in 1986 (Wang et al., 1986) and 2007 (Wang and $\mathrm{Hu}, 2007$ ) were used in this study. The land use data in 1965 was used for mapping with aerial photographs image processing and land use classification interpretation using the ERDAS and the ArcGIS software. The land use data in 1986 was clipped directly from the 1:100,000-scale land use database developed by the Chinese Academy of Sciences (CAS) (Liu et al., 2005). The land use data in 2007 was also clipped directly from images produced by the land use research project undertaken by CAREERI (Cold and Arid Regions Environmental and Engineering Research Institute, CAS). The land use classification system used by CAS (Liu et al., 2005) was adopted for all three datasets. The land use types in the classifications system included forest, sparse woodland, other forest, shrub, dense grassland, moderate grassland, sparse grassland, cropland, built-up land, water body, lowland, sandy land, gobi, swampland, alkaline land, and other unused land. The land use classification was conducted through visual interpretation to guarantee consistency and accuracy in the data processing. By field surveys and random sample checks, we confirmed that the overall interpretation accuracy of the land use classification was reliable. The procedures have been described in detail by Liu et al. (2005), Wang et al. (2007) and Wang and $\mathrm{Hu}$ (2007).

Groundwater data from 103 monitoring wells operated by the Gansu Provincial Bureau of Hydrology were collected. The depth of the groundwater table in January was determined on behalf of the annual groundwater depth because January is the month in which the groundwater table is relative least impacted by irrigation. The irrigation data were collected from annual water resource management reports (1980-2010) published by the Zhangye Municipal Bureau of Water Conservancy. Annual runoff data at the Yingluo, the Gaoya, and the Zhengyi gauge stations located in the mainstream of the Heihe River were obtained from the Gansu Provincial Bureau of Hydrology. All of the above-mentioned data were obtained from the Environmental and Ecological Science Data Center for West China (WestDC, http://westdc.westgis.ac.cn/) (Li et al., 2011).

\subsection{Methods}

Transition matrix of land use among 1965, 1986, and 2007 was used to compare land use change from the different periods of data. Water use data, including statistics on irrigation water volume and groundwater exploitation on the irrigation districts scale, were calculated for three periods of 1956-1989, 1990-1999, and 2000-2009. The relationships between the water use for canal irrigation, groundwater exploitation, and land use were analyzed for the study area.

We analyzed the spatial distribution of the groundwater depth and the variability of the groundwater during the period 1986-2007 in the study area using the geostatistics method based on the groundwater depths. In geostatistics, variogram can be used to describe the spatial variability and heterogeneity of environmental factors. The variogram is expressed as follows:

$$
\gamma(h)=\frac{1}{2 N(h)} \sum_{i=1}^{N(h)}\left[z\left(x_{i}\right)-z\left(x_{i}+h\right)\right]^{2} .
$$

Where $\gamma(h)$ is the semi-variogram, defined as one half of the variance of the difference between the attribute values at all points separated by $h$ (the distance interval), $N(h)$ is the total number of sample pairs of attributes that are separated by $h, z\left(x_{i}\right)$ and $z\left(x_{i}+h\right)$ are the values of variable $z$ at the spatial positions $x_{i}$ and $x_{i}+h$, respectively.

Assuming a normal distribution for the groundwater depth, a spatial interpolation model was created on the basis of the regionalized variables $z\left(x_{i}\right)$ and $z\left(x_{i}+h\right)$. The experimental variogram was fitted by a spherical model. The general expression of a spherical model is as follows:

$$
\gamma(h)=\left\{\begin{array}{c}
0, h=0 \\
c_{0}+c\left(\frac{3 h}{2 a}-\frac{1 h^{3}}{2 a^{3}}\right), 0<h \leqslant a . \\
c_{0}+c, h>a
\end{array}\right.
$$

Where $c_{0}$ is the nugget, $c$ is the partial sill, $c_{0}+c$ is the sill, $\alpha$ is the correlation length, and $h$ is the range.

The spheroid model was then applied to the ordinary kriging method used for the groundwater depth interpolation. Cross validation was used to determine whether the model and its associated set of parameter values were reasonable. All of the predicted values were compared with the observed values, and the model out- 
put was evaluated using the calculated statistics.

\section{Results and discussion}

\subsection{Land use change in the middle reaches of the Heihe River between 1965 and 2007}

Land use patterns in the middle reaches of the Heihe River Basin in 1965, 1986, and 2007 are shown in Fig. 2. Tables 1 and 2 show the land use change and the transition matrix during the 1965-1986 and 19862007 periods. The results showed that the land use in the study area changed significantly in the period 1965-2007, especially for cropland and grassland. The total area of cropland increased by approximately $21,591 \mathrm{hm}^{2}$ from 1965 to 1986 , with about $43.5 \%$ of cropland being converted from grassland, about $21 \%$ of cropland being converted from Gobi and sandy land. Total area of grassland decreased by $84,296 \mathrm{hm}^{2}$ from 1965 to 1986 . The results indicated that many ecologically significant lands were affected by the development of irrigation agriculture. In addition, the total areas of water bodies, lowland, and sandy and Gobi land decreased by approximately $3.19 \%, 3.95 \%$, and $0.68 \%$, respectively. Conversely, areas increased by $139.00 \%, 15.38 \%, 84.21 \%$, and $71.31 \%$ for forest, cropland, built-up land, and alkaline land, respectively during the same period. The main land use change from 1986 to 2007 was grassland reduction and cropland expansion, with about $56,611 \mathrm{hm}^{2}$ of decreased grassland area, and $58.8 \%$ of being converted into cropland, namely about $33,315 \mathrm{hm}^{2}$. Most of the new water-covered area in 2007 resulted from decreased grassland area. Along with the expansion of cropland, the number of water conservancy facilities increased as well, and the water-covered area increased by $4.17 \%$ from 1986 to 2007 . The results indicated the land use was more and more affected by artificial oasis development over the past 20 years. The area of ecologically significant land gradually decreased, whereas the amounts of cropland and land used for other productive purposes increased. This result is consistent with the findings of previous studies (Lu, 2003; Zhao et al., 2013). The spatial pattern of land use change over the past 40 years included that (a) the areas of cropland and built-up land in the irrigation districts steadily increased and (b) the spatial expansion of cropland occurred mainly in the upper and middle parts of the alluvial fan and the peripheral ex- tension of the existing oasis, and (c) the changes of grassland and forest were concentrated at the upper part of the alluvial fan and the river valley plain.

Figure 3 presents a detailed illustration of land use changes in the vicinity of the Liyuan River at the alluvial fan in the front of the mountain. The Liyuan River is one of the most important tributaries of the Heihe River and is the main water source for the Liyuan River irrigation district. The Liyuan River and its irrigation district were used to supply abundant grassland and forest in 1965 (Fig. 3b). Figure 3 presents a map of the transformation of land use during the periods 1965-1986 and 1986-2007. This map shows the significant transformations of land use among cropland, forest, and grassland in the irrigation district of the Liyuan River during the two periods. The increase in cropland during the period 1986-2007 contrasted sharply with the increase in grassland and forest during the period 1965-1986. The total area of cropland in the Liyuan River irrigation district increased by approximately 56\% during the period 1986-2007.

\subsection{Impacts of land use on water allocation in ir- rigation districts in the middle reaches of the Heihe River}

2.2.1 Spatial variation of the groundwater depth in the middle reaches of the Heihe River between 1986 and 2007

A trend analysis of the groundwater depth was performed with geostatistical method. The results indicated that the predicted groundwater depths agreed very well with the observed ones, confirming that the model and parameter values were reasonable. Table 3 shows that the sill and the nugget of the groundwater depth decreased significantly from 1986 to 2007, which indicates that the change in the groundwater depth occurred on both the stochastic and structural scales. The base effect values were distributed between $25 \%-75 \%$ during 1986 to 2007 and thus exhibited a moderate correlation. The decrease of the base effect and the increase of the variable range from 1986 to 2007 demonstrated that the higher spatial correlation and the lower spatial heterogeneity. These results indicated that the amounts of groundwater resources were restored.

Figure 4 illustrates the characteristics of the spatial distribution of the groundwater depths in the middle 

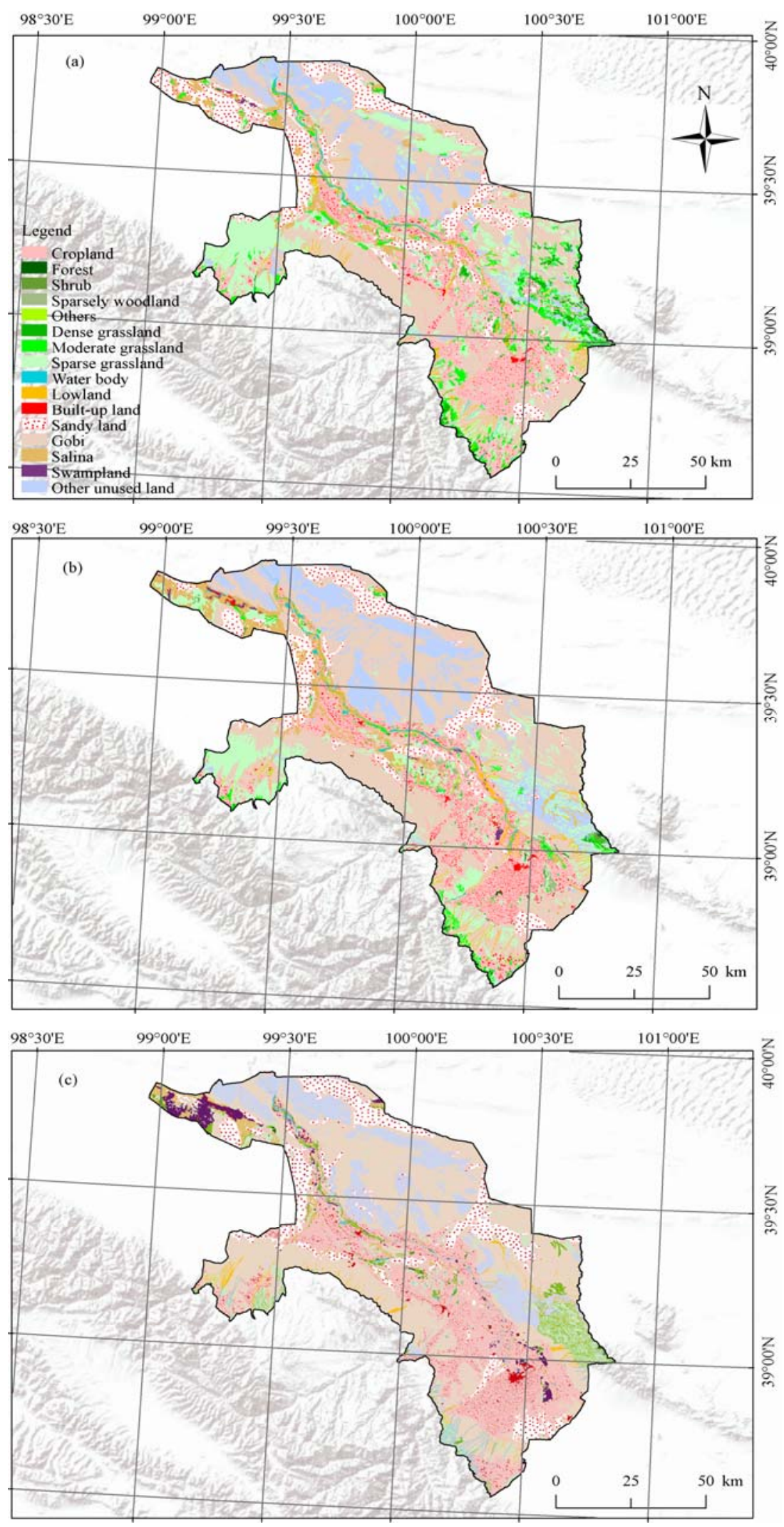

Fig. 2 Land use maps of the study area for (a) 1965, (b) 1986, and (c) 2007 
Table 1 Land use change in the irrigation districts of the middle reaches of the Heihe River

\begin{tabular}{|c|c|c|c|c|c|c|c|c|}
\hline \multirow[b]{2}{*}{ Land use type } & \multicolumn{4}{|c|}{ 1965-1986 } & \multicolumn{4}{|c|}{ 1986-2007 } \\
\hline & $\begin{array}{l}\text { Area in } \\
1965 \\
\left(\mathrm{hm}^{2}\right) \\
\end{array}$ & $\begin{array}{c}\text { Area in } \\
1986 \\
\left(\mathrm{hm}^{2}\right) \\
\end{array}$ & $\begin{array}{l}\text { Changed } \\
\text { values } \\
\left(\mathrm{hm}^{2}\right) \\
\end{array}$ & $\begin{array}{c}\text { Changed } \\
\text { percentage } \\
(\%)\end{array}$ & $\begin{array}{c}\text { Area in } \\
1986 \\
\left(\mathrm{hm}^{2}\right) \\
\end{array}$ & $\begin{array}{c}\text { Area in } \\
2007 \\
\left(\mathrm{hm}^{2}\right) \\
\end{array}$ & $\begin{array}{c}\text { Changed } \\
\text { values } \\
\left(\mathrm{hm}^{2}\right) \\
\end{array}$ & $\begin{array}{c}\text { Changed } \\
\text { percentage } \\
(\%) \\
\end{array}$ \\
\hline Forest & $6,337.77$ & $15,146.34$ & $8,808.58$ & 138.99 & $15,146.34$ & $6,984.97$ & $-8,161.37$ & -53.88 \\
\hline Grassland & $231,120.29$ & $146,824.47$ & $-84,295.82$ & -36.47 & $146,824.47$ & $90,213.58$ & $-56,610.88$ & -38.56 \\
\hline Cropland & $140,423.57$ & $162,014.68$ & $21,591.11$ & 15.38 & $162,014.68$ & $232,657.03$ & $70,642.35$ & 43.60 \\
\hline Built-up land & $8,935.51$ & $16,459.82$ & $7,524.30$ & 84.21 & $16,459.82$ & $15,590.94$ & -868.87 & -5.28 \\
\hline Water body & $7,439.04$ & $7,202.10$ & -236.93 & -3.19 & $7,202.10$ & $7,502.07$ & 300.00 & 4.17 \\
\hline Lowland & $19,149.70$ & $18,394.16$ & -755.54 & -3.95 & $18,394.16$ & $13,785.94$ & $-4,608.22$ & -25.05 \\
\hline Sandy land and Gobi & $462,892.58$ & $459,725.17$ & $-3,167.42$ & -0.68 & $459,725.17$ & $473,413.77$ & $13,688.60$ & 2.98 \\
\hline Alkaline land & $21,060.17$ & $36,078.51$ & $15,018.34$ & 71.31 & $36,078.51$ & $12,352.73$ & $-23,725.79$ & -65.76 \\
\hline Other used land & $92,076.33$ & $125,273.43$ & $33,197.10$ & 36.05 & $125,273.43$ & $116,539.72$ & $-8,733.71$ & -6.97 \\
\hline
\end{tabular}

Table 2 Transition matrix for land use data in the study area for 1965-1986 and 1986-2007

\begin{tabular}{|c|c|c|c|c|c|c|c|c|c|c|c|}
\hline \multirow{2}{*}{ Year } & \multirow{2}{*}{$\begin{array}{l}\text { Land use } \\
\text { type }\end{array}$} & Forest & Grassland & Cropland & $\begin{array}{l}\text { Built-up } \\
\text { land }\end{array}$ & $\begin{array}{l}\text { Water } \\
\text { body }\end{array}$ & Lowland & $\begin{array}{c}\text { Sandy } \\
\text { land }\end{array}$ & Gobi & $\begin{array}{c}\text { Alkaline } \\
\text { land }\end{array}$ & $\begin{array}{c}\text { Other } \\
\text { used land }\end{array}$ \\
\hline & & \multicolumn{10}{|c|}{$(\%)$} \\
\hline \multirow{10}{*}{ 1965-1986 } & Forest & 15.96 & 32.35 & 12.96 & 0.42 & 0.17 & 3.39 & 13.42 & 15.79 & 1.96 & 3.58 \\
\hline & Grassland & 0.68 & 56.48 & 6.11 & 0.18 & 0.51 & 1.85 & 12.05 & 16.40 & 2.83 & 2.91 \\
\hline & Cropland & 0.75 & 13.63 & 68.68 & 3.04 & 0.54 & 1.02 & 4.80 & 4.92 & 1.59 & 1.03 \\
\hline & $\begin{array}{l}\text { Built-up } \\
\text { land }\end{array}$ & 1.02 & 7.17 & 58.66 & 20.01 & 0.16 & 0.64 & 6.00 & 3.60 & 1.08 & 0.90 \\
\hline & Water body & 1.26 & 22.43 & 8.28 & 0.38 & 32.18 & 20.24 & 6.44 & 0.81 & 6.55 & 0.91 \\
\hline & Lowland & 0.91 & 29.21 & 10.21 & 0.17 & 10.87 & 26.34 & 7.56 & 12.17 & 1.22 & 1.34 \\
\hline & Sandy land & 0.38 & 7.07 & 0.52 & 0.00 & 0 & 0.13 & 82.85 & 6.76 & 1.78 & 0.51 \\
\hline & Gobi & 0.00 & 16.4 & 0.76 & 0.00 & 0.12 & 1.48 & 6.61 & 68.05 & 0.63 & 5.95 \\
\hline & $\begin{array}{c}\text { Alkaline } \\
\text { land }\end{array}$ & 0.76 & 25.00 & 6.64 & 0.67 & 1.70 & 4.40 & 32.86 & 3.10 & 23.44 & 0.94 \\
\hline & $\begin{array}{c}\text { Other used } \\
\text { land }\end{array}$ & 0.26 & 30.14 & 0.15 & 0.00 & 0.14 & 0.43 & 3.88 & 14.23 & 0.33 & 50.44 \\
\hline \multirow{10}{*}{ 1986-2007 } & Forest & 29.68 & 26.09 & 7.30 & 0.91 & 1.56 & 3.43 & 19.89 & 1.24 & 6.44 & 3.33 \\
\hline & Grassland & 3.40 & 40.82 & 3.04 & 0.15 & 1.22 & 3.74 & 7.55 & 12.86 & 10.38 & 16.62 \\
\hline & Cropland & 2.59 & 14.32 & 61.67 & 4.96 & 0.89 & 2.28 & 2.20 & 6.50 & 3.59 & 0.52 \\
\hline & $\begin{array}{l}\text { Built-up } \\
\text { land }\end{array}$ & 1.83 & 5.33 & 59.4 & 24.56 & 0.42 & 0.25 & 0.13 & 4.45 & 3.03 & 0.00 \\
\hline & Water body & 1.40 & 25.47 & 7.92 & 0.32 & 17.15 & 21.59 & 1.33 & 17.72 & 4.61 & 1.57 \\
\hline & Lowland & 0.68 & 26.20 & 3.38 & 0 & 6.52 & 18.38 & 0.66 & 31.15 & 1.35 & 11.59 \\
\hline & Sandy land & 0.73 & 3.34 & 0.79 & 0.04 & 0.06 & 0.28 & 63.15 & 24.39 & 2.67 & 4.51 \\
\hline & Gobi & 0.12 & 13.22 & 0.75 & 0.03 & 0.03 & 0.76 & 1.46 & 77.1 & 0.35 & 6.18 \\
\hline & $\begin{array}{l}\text { Alkaline } \\
\text { land }\end{array}$ & 3.22 & 25.63 & 0.98 & 0.74 & 0.39 & 0.00 & 11.72 & 5.02 & 49.84 & 1.55 \\
\hline & $\begin{array}{l}\text { Other used } \\
\text { land }\end{array}$ & 0.00 & 7.77 & 0.18 & 0.05 & 0.05 & 0.82 & 1.32 & 21.04 & 0.31 & 69.28 \\
\hline
\end{tabular}

reaches of the Heihe River Basin in 2007. The spatial distribution of the groundwater depth showed that the contour of groundwater depth was perpendicular to the direction of the Heihe River. The groundwater depth was relatively deep (10-50 m) at the alluvial fan in the front of the mountain. However, the depth became shallow
$(0-3 \mathrm{~m})$ in the river valley plain. Figure 5 further illustrates the groundwater depth changes during the period 1986-2007. Over the past 20 years, the groundwater depth has increased sharply at the upper and middle parts of the alluvial fan (3.0 to $21.5 \mathrm{~m}$ ). The change of groundwater depths in the river valley plain was less 

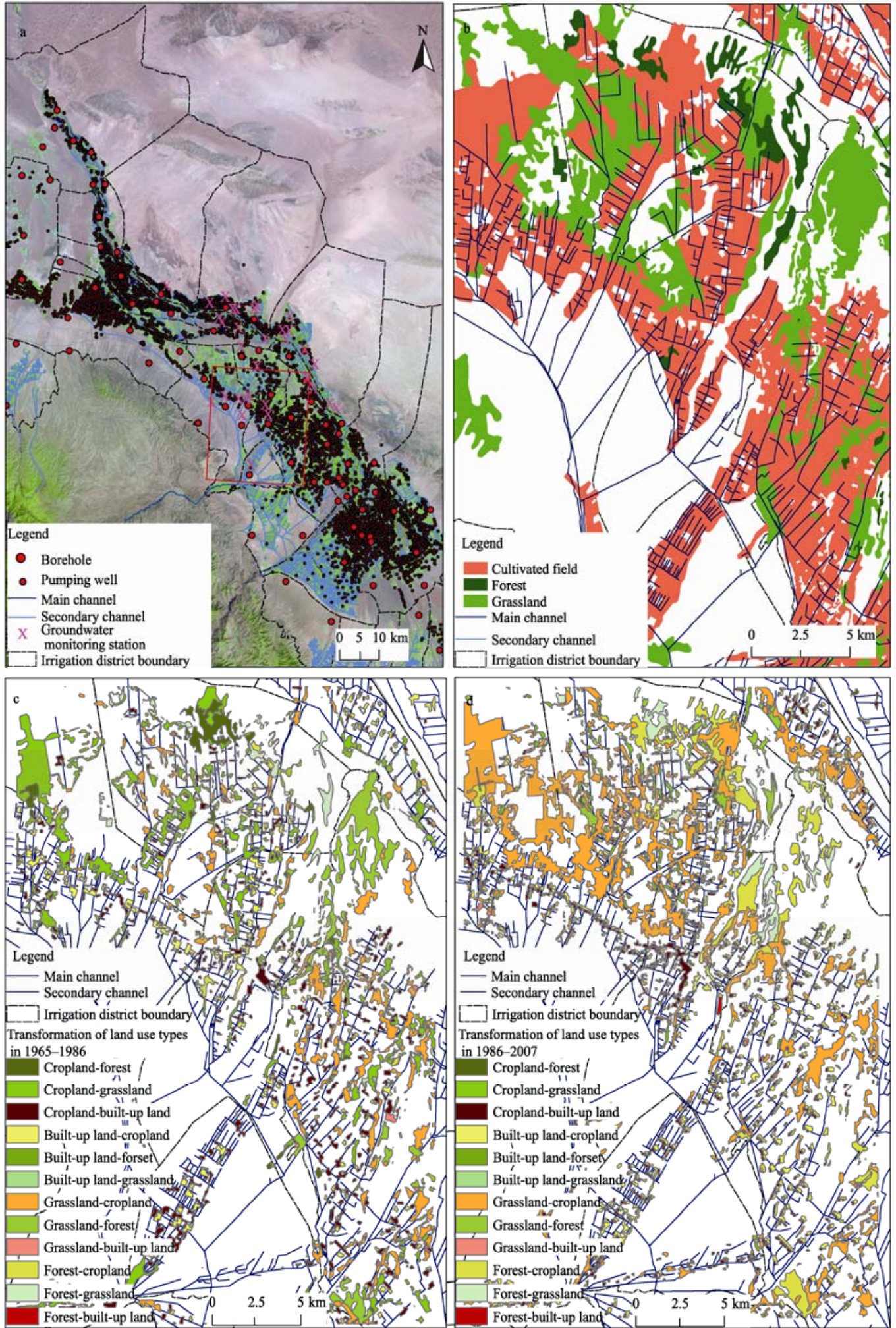

Fig. 3 Land use transformation in the Liyuan River irrigation district: (a) the location of the Liyuan River irrigation district, (b) the distributions of cultivated field, grassland, and forest in 1965, (c) the transformation map of land use during 1965-1986, (d) the transformation map of land use during 1986-2007. 
YanYun NIAN et al.: Impact of land use change on water resource allocation in the middle reaches of the Heihe...

Table 3 Model and related parameters for the semi-variogram of groundwater depths

\begin{tabular}{lcccccccc}
\hline & Model & Trend direction & Nugget & Sill & Base effect & Variable range & Step length & Group number \\
\hline Groundwater depth in 1986 & Spherical model & $129.90^{\circ}$ & 0.47 & 1.32 & 0.36 & 237,984 & 1,020 & 12 \\
Groundwater depth in 2007 & Spherical model & $111.80^{\circ}$ & 0.32 & 1.04 & 0.30 & 266,400 & 2,400 & 12 \\
\hline
\end{tabular}

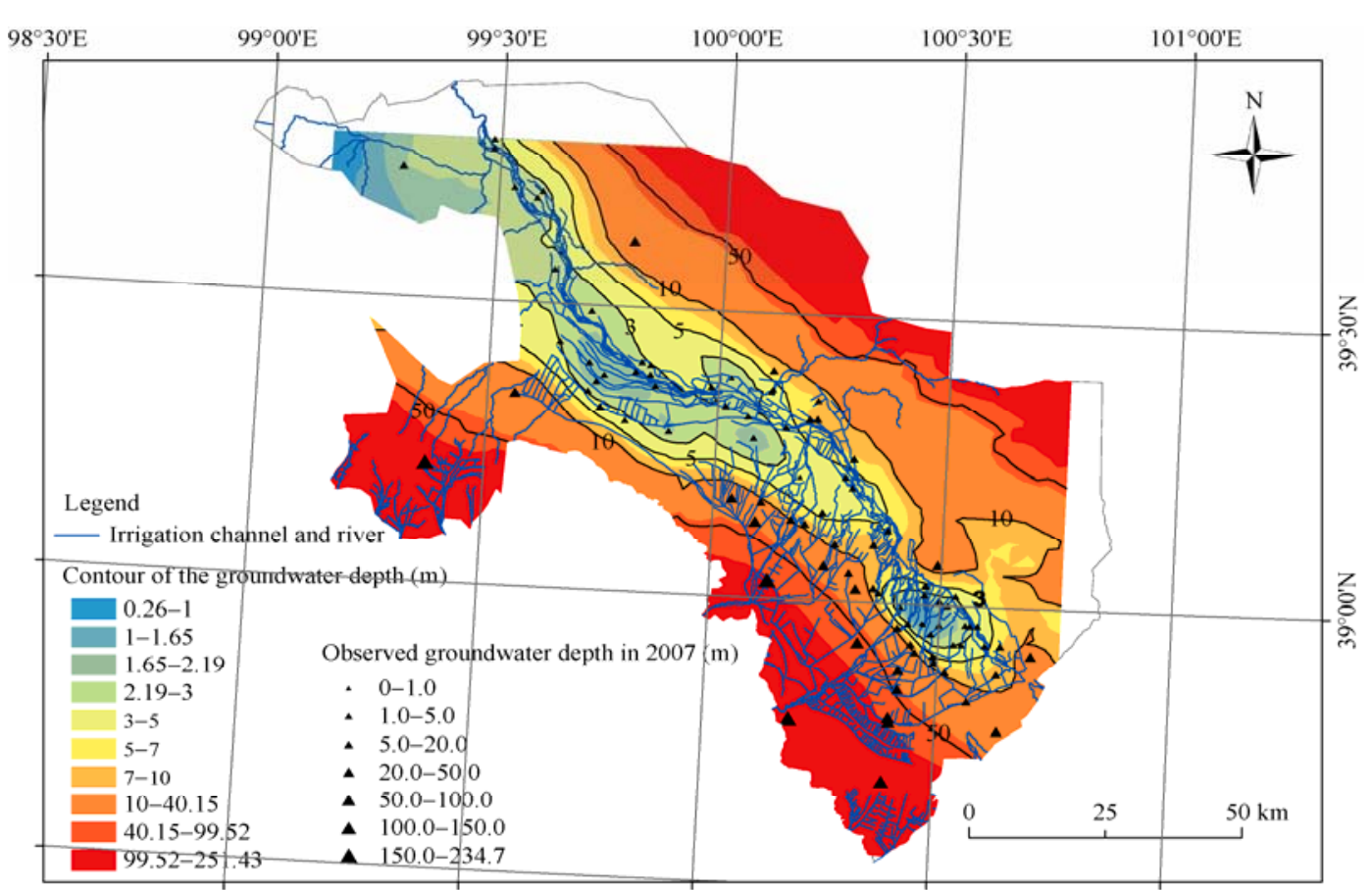

Fig. 4 Spatial interpolation of groundwater depths in the middle reaches of the Heihe River in 2007

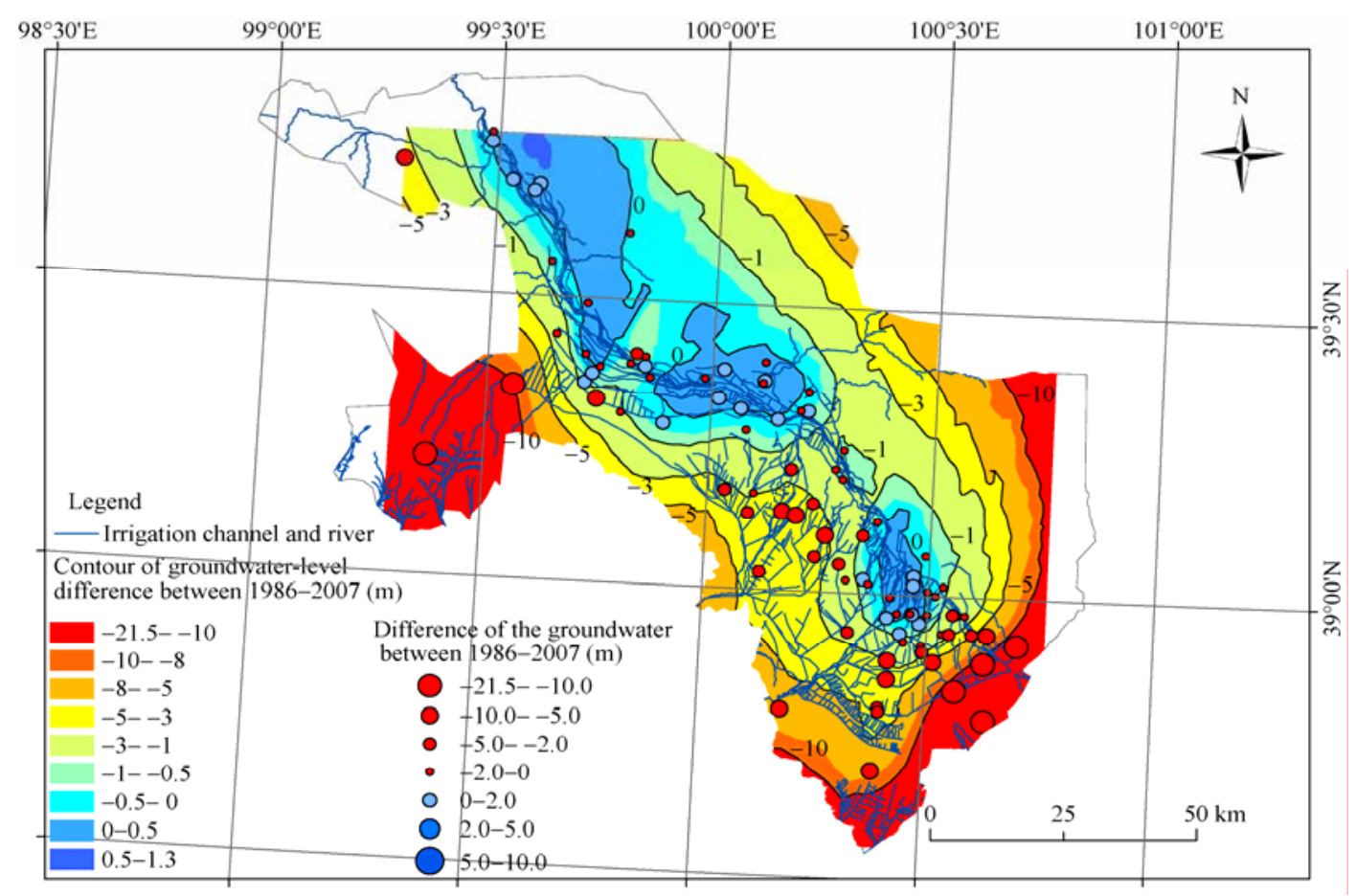

Fig. 5 Spatial interpolation of groundwater changes in the middle reaches of the Heihe River in 1986-2007 
than $1 \mathrm{~m}$ and maintained a stable state. Particularly, in the Liyuan River irrigation district, the expansion of the area of cultivated land resulted in the increase of groundwater exploitation and a $2-10 \mathrm{~m}$ drop in the groundwater table over the past 20 years. The numerical modeling results also indicated that the upper and middle parts of the alluvial fan in the front of the mountain were the groundwater recharge areas and that the river valley plain is the discharge region (Zhou et al., 2011). As the groundwater in the middle Heihe River Basin is hydraulically well connected, the groundwater flows continuously from the recharge area to the discharge area. During the past 20 years, the number of pumping wells has greatly increased to meet the demands of irrigation farming and urbanization. This increase in groundwater pumping has resulted in more groundwater discharge in the river valley plain. Therefore, the amount of groundwater resources recovered along the mainstream of the Heihe River.

2.2.2 Runoff change and water resource use in the middle reaches of the Heihe River Basin over the past 40 years

Figure 6a shows that the annual runoff was roughly divided into four stages at the Yingluo gauge station and the Zhengyi gauge station during the period 1963-
2010. The annual runoff had a declined trend before the late 1970s and the relative high-water period in the 1980s at the Yingluo gauge station. Then, the annual runoff has an increased trend since 2000, after experienced a drought period during the 1990s. The annual runoff at the Yingluo gauge station was $1.5 \times 10^{9}$ $\mathrm{m}^{3} / \mathrm{a}$ before the $1970 \mathrm{~s}, 1.74 \times 10^{9} \mathrm{~m}^{3} / \mathrm{a}$ in the $1980 \mathrm{~s}$, $1.58 \times 10^{9} \mathrm{~m}^{3} / \mathrm{a}$ in the $1990 \mathrm{~s}$, and $1.73 \times 10^{9} \mathrm{~m}^{3} / \mathrm{a}$ in the 2000s. The annual runoff at the Zhengyi gauge station was $1.13 \times 10^{9} \mathrm{~m}^{3} / \mathrm{a}$ before the $1970 \mathrm{~s}, 1.1 \times 10^{9} \mathrm{~m}^{3} / \mathrm{a}$ in the $1980 \mathrm{~s}, 0.77 \times 10^{9} \mathrm{~m}^{3} / \mathrm{a}$ in the $1990 \mathrm{~s}$, which indicated a trend of decreasing annual runoff to the lower reaches of the Heihe River Basin. After the implementation of the EWTP in 2001, the amount of water discharged entering into the low reaches reached up to $0.99 \times 10^{9}$ $\mathrm{m}^{3} / \mathrm{a}$ in the $2000 \mathrm{~s}$ and increased by $29 \%$ compared with the 1990s. The annual runoff difference between the Yingluo and the Zhengyi gauge stations, reflects to some extent the water resource consumption in the middle reaches of the Heihe River Basin, increased from $3.96 \times 10^{8} \mathrm{~m}^{3}$ in 1963 to $10.4 \times 10^{8} \mathrm{~m}^{3}$ at the end of $1990 \mathrm{~s}$, and then maintained steadily to $8.0 \times 10^{8} \mathrm{~m}^{3}$ in 2010 (as shown in Fig. 6b). The phenomena demonstrated that water volume for irrigation agriculture increased in the middle reaches of the Heihe River Basin owing to cropland expansion.

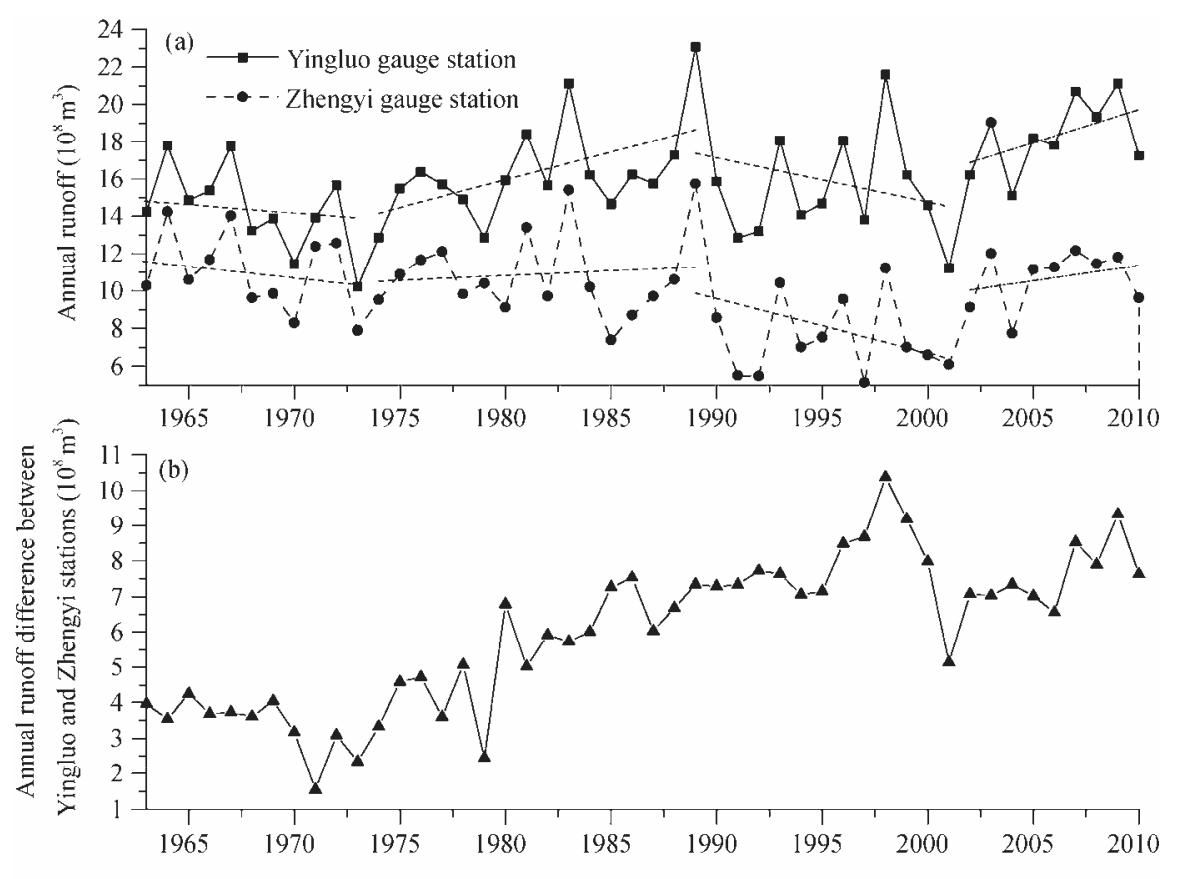

Fig. 6 Annual runoff and difference between the Yingluo and the Zhengyi gauge stations in the Heihe River Basin 
There are seventeen irrigation districts in the middle reaches of the Heihe River Basin. Figure 7 illustrates the component between average surface water use and average groundwater use in the major irrigation districts in the 2000s. The blue color in the pie chart represents groundwater exploitation, and the red color represents canal irrigation. The primary surface water sources for the irrigation districts are the main eastern and western canals, the mainstream of the Heihe River, and the Liyuan River in the middle of the Heihe River Basin. The main eastern canal, which feeds the three irrigation districts of Shangsan, Daman and Yingke, was assigned $4 \times 10^{8} \mathrm{~m}^{3} / \mathrm{a}$ of water in the $2000 \mathrm{~s}$. The main western canal, which controls the four irrigation districts of Ganjun, Xigan, Shahe and Luotuocheng, was assigned $2.5 \times 10^{8}$ $\mathrm{m}^{3} / \mathrm{a}$ of water in the $2000 \mathrm{~s}$. The irrigation districts of Yanuan, Banqiao, Pingchuan, Liaoquan, Sanqing, Youlian, Liuba, Dahuwan, and Luocheng, located in the lower portion of the middle reaches, consume surface water from the mainstream of the Heihe River.

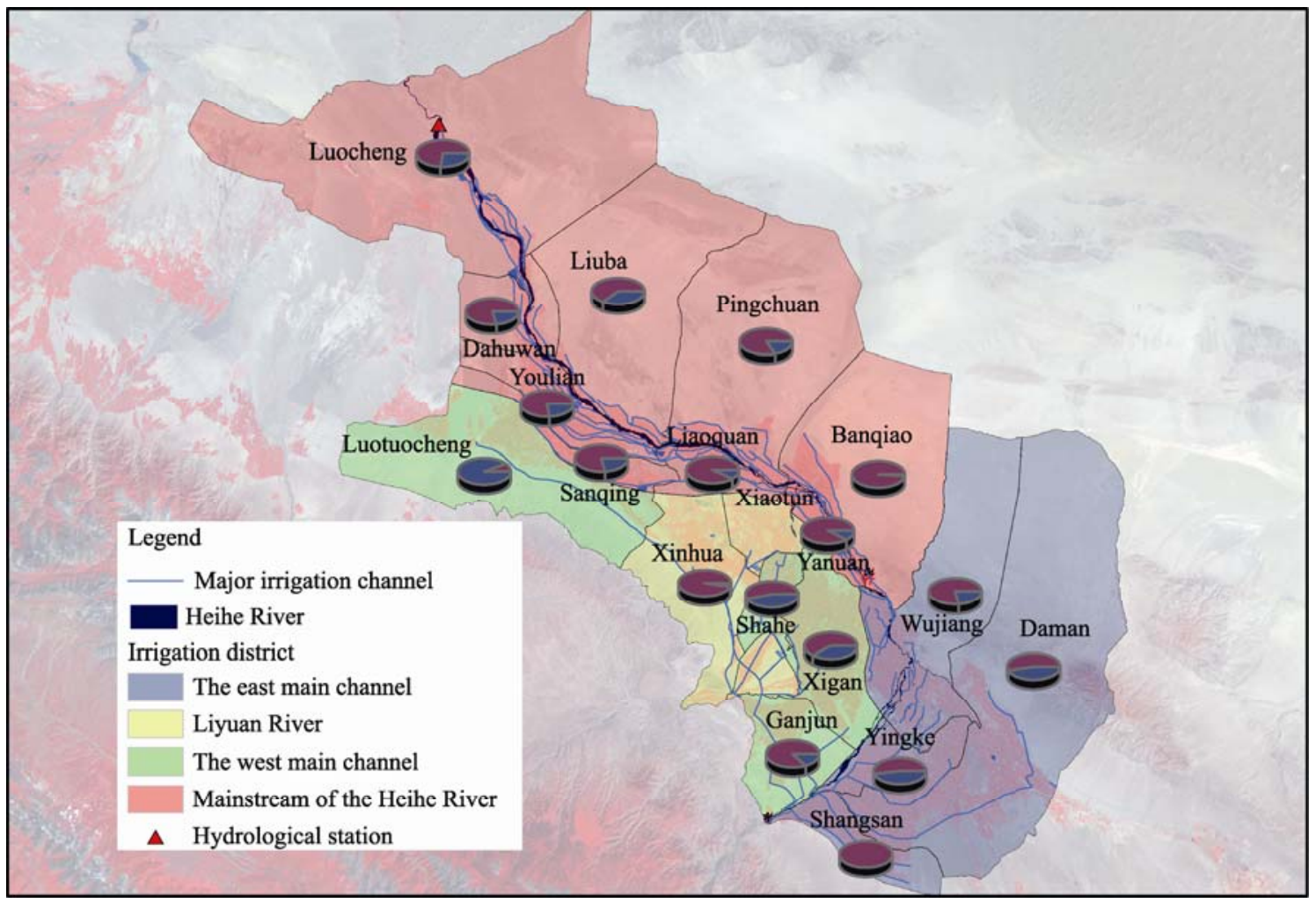

Fig. 7 The component between average surface water use and average groundwater use in the major irrigation districts in the 2000s

Table 4 shows temporal series proportions of water resources between surface water irrigation and groundwater exploitation for each irrigation districts in three periods of 1956-1989, 1990-1999 and 2000-2010. The total water diversion of both the main eastern and western canals was $5.23 \times 10^{8} \mathrm{~m}^{3} /$ a before 1989 and reached a peak of $7.052 \times 10^{8} \mathrm{~m}^{3} / \mathrm{a}$ in the 1990s. The total amount of water diversion of both the main eastern and western canals has stabilized at $6.91 \times 10^{8} \mathrm{~m}^{3} / \mathrm{a}$ since the implementation of the EWTP in 2001. The total groundwater exploitation for the continuously expanding cropland in the study area increased from $1.25 \times 10^{8} \mathrm{~m}^{3} / \mathrm{a}$ at the end of the $1980 \mathrm{~s}$ to $4.04 \times 10^{8} \mathrm{~m}^{3} / \mathrm{a}$ at the end of the $1990 \mathrm{~s}$ and reached $6.15 \times 10^{8} \mathrm{~m}^{3} / \mathrm{a}$ in 2010 . Overexploitation of groundwater is likely to be an indicator of unreasonable water resource utilization. For example, the amount of groundwater pumping increased dramatically from approximately $0.2 \times 10^{8} \mathrm{~m}^{3} / \mathrm{a}$ before 1989 to nearly $1.0 \times 10^{8} \mathrm{~m}^{3} / \mathrm{a}$ in the $2000 \mathrm{~s}$ in the four irrigation districts of Daman, Yingke, Xigan, and Luotuocheng, located at the upper and middle parts of the alluvial fan. Groundwater exploitation accounted for $46 \%$, $54.5 \%, 52 \%$ and $98.5 \%$ of total water resource use in 
the four irrigation districts, respectively. The overexploitation of water resources caused the groundwater depth to drop ranging from 1 to $5 \mathrm{~m}$ in these irrigation districts. In particular, in the Liyuan River irrigation district, the groundwater exploitation has increased 23-fold from 1950s to 2000s (Table 4). It is closely related to the increase in the area of cultivated land and the decreases in the areas of grassland and forest.

Table 4 Groundwater and surface water use in the middle reaches of the Heihe River during the period 1956-2010

\begin{tabular}{|c|c|c|c|c|c|c|c|c|c|c|}
\hline \multirow[b]{2}{*}{$\begin{array}{c}\text { Water } \\
\text { diversion }\end{array}$} & \multirow[b]{2}{*}{$\begin{array}{c}\text { Irrigation } \\
\text { unit }\end{array}$} & \multicolumn{3}{|c|}{ 1956-1989 } & \multicolumn{3}{|c|}{ 1990-1999 } & \multicolumn{3}{|c|}{$2000-2010$} \\
\hline & & $\begin{array}{c}\text { Canal irrigation } \\
\left(10^{8} \mathrm{~m}^{3} / \mathrm{a}\right) \\
\end{array}$ & $\begin{array}{c}\text { Groundwater } \\
\left(10^{8} \mathrm{~m}^{3} / \mathrm{a}\right)\end{array}$ & $\begin{array}{c}\text { Well } \\
\text { numbers }\end{array}$ & $\begin{array}{c}\text { Canal irrigation } \\
\left(10^{8} \mathrm{~m}^{3} / \mathrm{a}\right)\end{array}$ & $\begin{array}{c}\text { Groundwater } \\
\left(10^{8} \mathrm{~m}^{3} / \mathrm{a}\right)\end{array}$ & $\begin{array}{c}\text { Well } \\
\text { Numbers } \\
\end{array}$ & $\begin{array}{c}\text { Canal irrigation } \\
\left(10^{8} \mathrm{~m}^{3} / \mathrm{a}\right) \\
\end{array}$ & $\begin{array}{c}\text { Ground-water } \\
\left(10^{8} \mathrm{~m}^{3} / \mathrm{a}\right)\end{array}$ & $\begin{array}{c}\text { Well } \\
\text { numbers }\end{array}$ \\
\hline \multirow{3}{*}{$\begin{array}{c}\text { Western } \\
\text { main canal }\end{array}$} & Shangsan & 0.43 & 0.006 & 8 & 0.83 & 0.010 & 13 & 1.00 & 0.013 & 19 \\
\hline & Daman & 1.20 & 0.250 & 224 & 1.63 & 0.730 & 487 & 1.36 & 1.190 & 755 \\
\hline & Yingke & 1.70 & 0.220 & 265 & 1.65 & 0.960 & 687 & 1.60 & 1.440 & 1,115 \\
\hline \multirow{4}{*}{$\begin{array}{c}\text { Eastern } \\
\text { main canal }\end{array}$} & Ganjun & 0.50 & 0.003 & 4 & 0.84 & 0.005 & 7 & 0.90 & 0.007 & 14 \\
\hline & Xigan & 1.20 & 0.250 & 151 & 1.65 & 0.690 & 353 & 1.70 & 1.120 & 582 \\
\hline & Shahe & 0.20 & 0.030 & 12 & 0.44 & 0.100 & 53 & 0.27 & 0.230 & 129 \\
\hline & $\begin{array}{l}\text { Luotuo } \\
\text { cheng }\end{array}$ & & 0.190 & 129 & 0.01 & 0.810 & 449 & 0.08 & 0.990 & 562 \\
\hline \multicolumn{2}{|c|}{ Total of the canal } & 5.23 & & 793 & 7.05 & & 2,049 & 6.91 & & 3,176 \\
\hline \multirow{9}{*}{$\begin{array}{l}\text { Heihe } \\
\text { River }\end{array}$} & Yanuan & 0.30 & 0.006 & 8 & 0.63 & 0.018 & 16 & 0.44 & 0.088 & 79 \\
\hline & Liaoquan & 0.40 & 0.004 & 17 & 0.96 & 0.022 & 55 & 0.58 & 0.067 & 191 \\
\hline & Banqiao & 0.40 & 0.002 & 13 & 1.05 & 0.002 & 15 & 1.13 & 0.025 & 84 \\
\hline & Pingchuan & 0.60 & 0.018 & 50 & 1.05 & 0.075 & 144 & 0.72 & 0.177 & 337 \\
\hline & Sanqing & 0.30 & 0.005 & 17 & 0.50 & 0.024 & 74 & 0.50 & 0.054 & 153 \\
\hline & Youlian & 0.50 & 0.160 & 312 & 1.10 & 0.240 & 502 & 0.67 & 0.285 & 595 \\
\hline & Dahuwan & 0.24 & 0.046 & 163 & 0.37 & 0.065 & 249 & 0.50 & 0.069 & 276 \\
\hline & Liuba & 0.15 & 0.051 & 163 & 0.25 & 0.072 & 226 & 0.20 & 0.080 & 252 \\
\hline & Luocheng & 0.17 & 0.003 & 113 & 0.22 & 0.153 & 141 & 0.26 & 0.153 & 159 \\
\hline $\begin{array}{c}\text { Liyuan } \\
\text { River }\end{array}$ & $\begin{array}{c}\text { Liyuan } \\
\text { River }\end{array}$ & 0.90 & 0.006 & 6 & 1.49 & 0.064 & 77 & 1.22 & 0.164 & 194 \\
\hline \multicolumn{2}{|c|}{ Total of the river } & 3.96 & & 862 & 7.62 & & 1,499 & 6.22 & & 2,320 \\
\hline \multicolumn{2}{|c|}{ Total of the water use } & 9.19 & 1.250 & 1,655 & 14.67 & 4.040 & 3,548 & 13.13 & 6.152 & 5,496 \\
\hline
\end{tabular}

\section{Conclusions}

In this study, land use and water resource data over the past four decades were utilized to quantitatively analyze the effects of land use change on water resource use in the middle reaches of the Heihe River Basin. Land use has experienced dramatic changes in the middle reaches of the Heihe River Basin. The area of natural grassland decreased from $231,120 \mathrm{hm}^{2}$ in 1965 to $90,213 \mathrm{hm}^{2}$ in 2007 and the area of cropland increased from $140,420 \mathrm{hm}^{2}$ in 1965 to $232,653 \mathrm{hm}^{2}$ in 2007. Land use changes have resulted in continuous increase in the demand for agricultural water in the irrigation districts of the Heihe River since the 1960s, which means that land use changes caused by anthro- pogenic activities have been the key factor influencing the development of water resources. Along with the continuous expansion of the cultivated land in the middle reaches of the Heihe River Basin, water-related conflicts became increasingly obvious. The canal irrigation and overexploitation of groundwater constantly increased for satisfying requirement of water supply in the study area, which led to the problem of irrational water allocation in the irrigation districts of the middle Heihe River Basin. Integrated planning and rational allocation of water resources in the study areas are needed.

The objective of the EWTP is to make the allocation of water resources more reasonable and efficient. The implementation of the EWTP since 2001 has guaranteed a certain volume of runoff entering into the 
lower reaches of the Heihe River Basin. Meanwhile, the irrigation water resource in the middle Heihe River Basin has also increased owing to annual runoff increase at the mouth of the mountain valley resulted from increasing precipitation in the upper reaches of the Heihe River Basin in the 2000s. Additional infiltration allowed groundwater recovery in the middle reaches. However, further expansion of cropland in irrigation districts should be restricted, and the efficiency of surface water resources use should be improved by mulching with plastic film and drip irrigation technology. In total, the sustainable allocation of water resources in arid inland river basins can only be achieved by the rational allocation of surface water and groundwater resources throughout the river basin.

\section{Acknowledgements}

The work was supported by the Chinese Academy of Sciences Action Plan for West Development Program Project (KZCX2-XB3-15), the National Natural Science Foundation of China (91125023), and the Fundamental Research Funds for the Central Universities in China (lzujbky-2011-131). We also thank the editors and anonymous reviewers who provided valuable comments.

\section{References}

Baker T J, Miller S N. 2013. Using the Soil and Water Assessment Tool (SWAT) to assess land use impact on water resources in an East African watershed. Journal of Hydrology, 486: 100-111.

Calow R C, Robins N S, MacDonald A M. 1997. Groundwater management in drought-prone areas of Africa. International Journal of Water Resources Development, 13(2): 241-262.

Chen X, Yan J F, Chen Z. 2009. A spatial geostatistical analysis of impact of land use development on groundwater resources in the Sangong Oasis Region using remote sensing imagery and data. Journal of Arid Land, 1(1): 1-8.

Chen Y N, Zilliacus H, Li W H. 2006. Ground-water level affects plant species diversity along the lower reaches of the Tarim River, Western China. Journal of Arid Environments, 66(2): 231-246.

Choi W, Deal B M. 2008. Assessing hydrological impact of potential land use change through hydrological and land use change modeling for the Kishwaukee River basin (USA). Journal of Environmental Management, 88(4): 1119-130.

DeFries R, Eshleman N K. 2004. Land-use change and hydrologic processes: a major focus for the future. Hydrological Processes, 18 (11): 2183-2186.

Foley J A, DeFries R, Asner G P. 2005. Global consequences of land use. Science, 309(5734): 570-574.
Gao Q Z, Li F X. 1991. Rational Exploitation of Water Resources in the Heihe River Basin. Lanzhou: Gansu Science and Technology Press, 78-228.

Guo Q L, Yang Y S, Chen Z H. 2010. Ecological water requirements of vegetation in Ejina oasis. Journal of Water Resources \& Water Engineering, 21(003): 80-84.

Hoff H. 2002. The water challenge: joint water project. Global Change Newsletter, 50: 46-48.

Houghton R A. 1994. The worldwide extent of land-use change. Bioscience, 44(5): 305-313.

Im S, Kim H, Kim C, Jang C. 2009. Assessing the impacts of land use changes on watershed hydrology using MIKE SHE. Environmental Geology, 57(1): 231-239.

Ji X B, Kang E S, Chen R S. 2006. The impact of the development of water resources on environment in arid inland river basins of Hexi region, Northwestern China. Environmental Geology, 50(6): 793-801.

Jin X M, Hu G C. 2010. Vegetation change and estimation of the smallest water demand of Ejina oasis in lower reaches of Heihe River. Advance in Science and Technology of Water Resources, 30(1): 30-34.

Lambin E F. 1997. Modelling and monitoring land-cover change processes in tropical regions. Progress in Physical Geography, 21(3): 375-393.

Lambin E F, Baulies X, Bockstael N E. 2002. Land-use and Land-cover Change Implementation Strategy, IGBP Report No. 48/IHDP Report No. 10, Stockholm: IGBP and IHDP, 65-125.

Leng C, Chen Y N, Li X G. 2011. Evaluation of oasis stability in the lower reaches of the Tarim River. Journal of Arid Land, 3(2): $123-131$.

Li X, Lu L, Cheng G D. 2001. Quantifying landscape structure of the Heihe River Basin, north-west China using FRAGSTATS. Journal of Arid Environments, 48(4): 521-535.

Li X, Nan Z T, Cheng G D. 2011. Toward an improved data stewardship and service for environmental and ecological science data in West China. International Journal of Digital Earth, 4(4): 347-359.

Liu J Y, Liu M L, Tian H Q. 2005. Spatial and temporal patterns of China's cropland during 1990-2000: An analysis based on Landsat TM data. Remote Sensing of Environment, 98(4): 442-456.

Loveland T R, Reed B C, Brown J F. 2000. Development of a global land cover characteristics database and IGBP DISCover from $1 \mathrm{~km}$ AVHRR data. International Journal of Remote Sensing, 21(6-7): 1303-1330.

Lu L, Li X, Cheng G D. 2003. Landscape evolution in the middle Heihe River Basin of north-west China during the last decade. Journal of Arid Environments, 53(3): 395-408.

Mellander P E, Gebrehiwot S G, Gardenas A I, et al. 2013. Summer rains and dry seasons in the Upper Blue Nile Basin: the predictability of half a century of past and future spatiotemporal patterns. Plos One, 8(7): 1932-6203. 
Ozturk M, Copty N K, Saysel A K. 2013. Modeling the impact of land use change on the hydrology of a rural watershed. Journal of Hydrology, 497: 97-109.

Pielke R A, Marland G, Betts R A. 2002. The influence of land-use change and landscape dynamics on the climate system: relevance to climate-change policy beyond the radiative effect of greenhouse gases. Philosophical Transactions of the Royal Society of London. Series A: Mathematical, Physical and Engineering Sciences, 360(1797): 1705-1719.

Qi S Z, Luo F. 2006. Land-use change and its environmental impact in the Heihe River Basin, arid northwestern China. Environmental Geology, 50(4): 535-540.

Raini J A. 2009. Impact of land use changes on water resources and biodiversity of Lake Nakuru catchment basin, Kenya. African Journal of Ecology, 47(Suppl. 1): 39-45.

Scanlon B R, Reedy R C, Tachovsky J A. 2007. Semiarid unsaturated zone chloride profiles: Archives of past land use change impacts on water resources in the southern High Plains, United States. Water Resources Research, 43, W06423.

Turner M G, Pearson S M, Bolstad P. 2003. Effects of land-cover change on spatial pattern of forest communities in the Southern Appalachian Mountains (USA). Landscape Ecology, 18(5): 449-464.

Wagner P D, Kumar S, Schneider K. 2013. An assessment of land use change impacts on the water resources of the Mula and Mutha Rivers catchment upstream of Pune, India. Hydrology and Earth System Sciences, 17(6): 2233-2246.

Wang G X. 1997. Analysis of rational utilization of water resources in Eijina green district of Heihe River, Nei Mongol. Journal of Lanzhou University: Natural Sciences, 33(3): 111-116.

Wang G X, Cheng G D. 2000. The characteristics of water resources and the changes of the hydrological process and environment in the arid zone of northwest China. Environmental Geology, 39(7): 783-790.
Wang G X, Cheng G D, Shen Y P. 2002. Dynamic tendency of arid oasis under the influence of water resources decrease-a case study of Ejina oasis in Heihe River Basin. Chinese Journal of Applied Ecology, 13(5): 564-568.

Wang G X, Liu J Q, Kubota J. 2007. Effects of land-use changes on hydrological processes in the middle basin of the Heihe River, northwest China. Hydrological Processes, 21(10): 1370-1382.

Wang G X, Yang L Y, Chen L. 2005. Impacts of land use changes on groundwater resources in the Heihe River Basin. Journal of Geographical Sciences, 15(4): 405-414.

Wang G X, Zhou J, Kubota J. 2008. Evaluation of groundwater dynamic regime with groundwater depth evaluation indexes. Water Environment Research, 80(6): 547-560.

Wang J H, Hu X L. 2007. Research on Land Use and Land Cover Change of Zhangye City in 2007. Lanzhou: Cold and Arid Regions Environmental and Engineering Research Institute, 1-60.

Wang Y M, Yan C Z, Wang J H. 1986. Land Use Map of the Heihe River Basin in 1986. Lanzhou: Cold and Arid Regions Environmental and Engineering Research Institute.

Zhang Y C, Yu J J, Qiao M Y. 2011. Effects of eco-water transfer on changes of vegetation in the lower Heihe River basin. Journal of Hydraulic Engineering, 7(7): 757-765.

Zhao R F, Chen Y N, Shi P J. 2013. Land use and land cover change and driving mechanism in the arid inland river basin: a case study of Tarim River, Xinjiang, China. Environmental Earth Sciences, 68(2): 591-604.

Zhao W Z, Chang X L, He Z B. 2007. Study on vegetation ecological water requirement in Ejina Oasis. Science in China Series D: Earth Sciences, 50(1): 121-129.

Zhou J, Hu B X, Cheng G D, et al. 2011. Development of a three-dimensional watershed modelling system for water cycle in the middle part of the Heihe rivershed, in the west of China. Hydrological Processes, 25(12): 1964-1978. 